\title{
Respon Pertumbuhan dan Hasil Tanaman Bunga Gladiol (Gladiolus hibridus) Terhadap Penggunaan Media Tanam dan Pupuk Saputra Nutrien.
}

\section{Growth and Yield Response Plants Gladiolus (Gladiolus hibridus) Against the Use of Media and Fertilizer Plant Nutrient Saputra.}

\author{
Yunus Laing ${ }^{1}$, Tutik Nugrahini ${ }^{1}$ dan Mahdalena ${ }^{1}$ \\ ${ }^{1}$ Alumni Program Studi Agroteknologi, Fakultas Pertanian, Universitas Widya Gama Mahakam \\ ${ }^{2}$ Tenaga Pendidik Program Studi Agroteknologi, Fakultas Pertanian, Universitas Widya Gama Mahakam \\ Jl. KH. Wahid Hasyim, Sempaja, Samarinda, Kalimantan Timur, Indonesia. \\ email : yunuslg@gmail.com, tutik_nugrahini@yahoo.com, mahdalen@yahoo.co.id
}

Diterima : 10 April 2012 Disetujui : 3 Mei 2012

\section{ABSTRACT}

Growth and yield response Gladiolus flowers (Gladiolus Hibridus) against the use of growing media and fertilizers Saputra Nutrient. This study aims to determine Saputra Nutrient fertilizer use and the use of growing media on growth and yield of flowers gladiolus (Gladiolus hibridus). The research was conducted from April to July 2010. The study was conducted in North Samarinda. This study uses a randomized block design (RAK) with a $4 \times 3$ factorial experiment consisted of three replications. The first factor is the use of a planting medium that consists of three levels ie: $\mathrm{ml}$ (top soil), $m 2$ (top soil + manure + husk), $m 3$ (top soil + manure + sand), the second factor is the use of fertilizers Saputra Nutrient consisting of 4 levels ie: p0 levels (without fertilizer), p1 (1 tablespoon powder +3 tablespoons liquid +7.5 liters of water), $p 2$ (1 tablespoon powder +3 tablespoons liquid +5.0 liters of water), and 33 (1 spoon 3 tablespoons of powder + liquid +2.5 liters of water). The results showed that the use of the planting medium significantly affected all parameters of the study except the number of leaves at 15 days after planting. Treatment $\mathrm{ml}$ (top soil) showed the largest number of flowers cropping 13.96 florets. The results showed that the use of fertilizers Saputra Nutrient significantly affected all parameters except the current study appear shoots number of leaves at 15 days after planting. Treatment 22 (1 tablespoon powder +3 tablespoons liquid +5.0 liters of water), showed the largest amount of 14.00 florets florets. Interaction of growing media and fertilizer use Saputra Nutrient no real effect on all parameters of observation.

Keywords: gladiolus flower, growing media and Saputa Nurtrien

\section{PENDAHULUAN}

Dalam sejarah Mesir, Yunani, Romawi dan Cina penyelenggaraan tanaman hias dikerjakan dengan seksama. Di dasari bahwa keindahan yang hidup diperlukan di sekeliling kita. Keindahan sederhana, tidak perlu menuntut biaya dan tenaga kita dapatkan dari tanaman hias. Arti penting tanaman hias dalam kehidupan manusia, menyadari orang untuk mengusahakan dan mencari jenis - jenis tanaman hias yang menarik (Winata, 1985).

Salah satu komoditas hortikultura yang ditingkatkan karena memiliki potensi ekspor adalah tanaman hias, terutama bunga potong (Ashari, 1995). Prospek agribisnis bunga potong cendrung makin cerah. Kebutuhan pasar dalam negeri akan termasuk bunga potong belum terpenuhi. Kondisi ini memberikan peluang untuk mengusahakan dan mengelola bunga potong, sehingga akan meningkatkan pendapatan masyarakat yang mengusahakan. Permintaan akan bunga potong meningkat pada saat menjelang Idul Fitri, Natal, Tahun Baru dan hari - hari besar lainya (Rukmana, 2000). Sebagai negara tropis yang memiliki dataran tinggi dan dataran rendah, Indonesia mampu menghasilkan bermacammacam tanaman hotikultura terutama tanaman hias penghasil bunga potong, baik yang tropis maupun subtropis (Herlina, 1991).

Tanaman gladiol merupakan salah satu jenis penghasil bunga potong yang berpotensi untuk dikembangkan. Permintaan bunga potong terus meningkat seiring dengan peningkatan pendapatan masyarakat dan industri parawisata (Rukmana, 2000).

Pengenalan bunga potong gladiol di Kalimantan Timur kurang sehingga tidak pada petani yang mengusahakannya. Hal ini perlu di lakukan Pembinaan kelembagaan, permodalan dan informasi serta persepsi bahwa tanaman gladiol hanya tumbuh di pulau Jawa. Tanaman gladiol dapat tumbuh baik dan berbunga pada dataran rendah asalkan dipelihara dan dipupuk (Olieve Wisje, 1994). Kalimantan Timur ditinjau dari iklim dan tanahnya dapat mendukung pertumbuhan tanaman gladiol. Meskipun tanah di Kalimantan Timur dapat dikatagorikan sebagai tanah yang mempunyai daya dukung rendah, kandungan unsur hara seperti N, P dan K rendah sehingga status kesuburan tanahnya rendah, namun hal tersebut dapt di tanggulangi dengan pemupukan (Riyanto dan Seohartini Riyanto, 1981). Tanaman gladiol dapat diperbanyak dengan biji (generatif) dan subang (vegetatif). Perbanyakan generatif biasanya dipraktekkan pada penelitian dan pemuliaan tanaman, dengan 
tujuan mendapatkan varietas atau kultival baru. Perbanyakan vegetatif dapat diperbanyakan dengan subang utuh, anak subang, subang belah maupun kultur jaringan. Perbanyakan vegetataif umumnya dilakukan untuk menghasilkan bibit produksi. Perbanyakan menggunakan subang lebih banyak digunakan karena selain dapat menghemat waktu dan biaya pembibitan gladiol juga dapat dipercepatnya waktu bertanam (Asgar dkk., 1995).

\section{BAHAN DAN METODE}

Penelitian ini dilaksanakan dari bulan April sampai dengan Juli 2010, mulai persiapan tempat sampai pengambilan data terakhir. Penelitian dilaksanakan di Samarinda Utara. Bahan yang digunakan dalam penelitian ini adalah bibit bunga gladiol varietas hibrida yang berwarna kuning cerah, pupuk Saputra Nutrien (Bubuk dan Cair), pupuk kandang, Dithane M-45 dan furadan 3G. Alat yang digunakan dalam penelitian ini adalah polybag yang berukuran $30 \times 40 \mathrm{~cm}$, penggaris, timbangan, alat dokumentasi, pisau, meteran, hendsprayer dan leaf area meter. Penelitian menggunakan Rancangan Acak Kelompok dengan pola faktorial 4 x 3 dengan 3 ulangan Faktor pertama adalah media tanam yang terdiri dari 3 taraf yaitu : Faktor pertama penggunaan media
Pemberian pupuk Saputra Nutrien merupakan usaha untuk meningkatkan penyerpan unsur hara dan mengaktifkan organisme dalam tanah, selain itu juga dapat memperbaiki kesuburan tanah sehingga mudah dalam penyerapan. Selain dari pemberian pupuk, faktor yang mempengaruhi kesuburan tanaman yaitu media tanam yang tepat bagi tanaman.

tanam yang terdiri dari 3 taraf yaitu : $\mathrm{m}_{1}$ (top soil), $\mathrm{m}_{2}$ (top soil + pupuk kandang + sekam), $\mathrm{m}_{3}$ (top soil + pupuk kandang + pasir), Faktor kedua penggunaan pupuk Saputra Nutrien yang terdiri dari 4 taraf yaitu : $\mathrm{p}_{0}$ taraf (tanpa pupuk), $\mathrm{p}_{1}$ (1 sendok makan powder +3 sendok liquid $+7,5$ liter air), $\mathrm{p}_{2}$ (1 sendok makan powder +3 sendok liquid $+5,0$ liter air), dan $\mathrm{p}_{3}$ (1 sendok powder +3 sendok liquid $+2,5$ liter air). Pengambilan data meliputi ; waktu muncul tunas, tinggi tanaman, jumlah daun, umur berbunga, panjang tangkai bunga, jumlah kuntum bunga per tangkai dan umur tanaman saat panen bunga. Data hasil penelitian dianalisis dengan sidik ragam. Apabila terdapat perbedaan yang nyata, maka untuk membandingkan antara dua rata-rata perlakuan dilanjutkan dengan Uji Beda Nyata Terkecil (BNT) pada taraf $5 \%$.

\section{HASIL DAN PEMBAHASAN}

Tabel 1. Rata-Rata Saat Muncul Tunas pada Perlakuan Media Tanam

\begin{tabular}{cc}
\hline Media Tanam & Saat muncul tunas (hari) \\
\hline $\mathrm{m}_{1}$ & $7,39^{\mathrm{a}}$ \\
$\mathrm{m}_{2}$ & $8,80^{\mathrm{b}}$ \\
$\mathrm{m}_{3}$ & $7,72^{\mathrm{a}}$ \\
\hline
\end{tabular}

Keterangan : Angka-angka yang diikuti huruf yang sama menunjukkan tidak berbeda nyata berdasarkan uji BNT pada taraf $\alpha=5 \%$

Tabel 2. Rata-Rata Tinggi Tanaman pada Perlakuan Media Tanam

\begin{tabular}{ccccc}
\hline \multirow{2}{*}{ Media Tanam } & \multicolumn{4}{c}{ Tinggi Tanaman $(\mathrm{cm})$ pada Umur Tanaman } \\
\cline { 2 - 5 } & $15 \mathrm{hst}$ & $30 \mathrm{hst}$ & $45 \mathrm{hst}$ & $60 \mathrm{hst}$ \\
\hline $\mathrm{m}_{1}$ & $12,29^{\mathrm{b}}$ & $33,70^{\mathrm{b}}$ & $55,07^{\mathrm{b}}$ & $64,59^{\mathrm{b}}$ \\
$\mathrm{m}_{2}$ & $9,78^{\mathrm{a}}$ & $27,18^{\mathrm{a}}$ & $49,45^{\mathrm{a}}$ & $56,88^{\mathrm{a}}$ \\
$\mathrm{m}_{3}$ & $10,10^{\mathrm{a}}$ & $29,54^{\mathrm{a}}$ & $51,62^{\mathrm{ab}}$ & $61,55^{\mathrm{ab}}$ \\
\hline
\end{tabular}

Keterangan : Angka-angka yang diikuti huruf yang sama menunjukkan tidak berbeda nyata berdasarkan uji BNT pada taraf $\alpha=5 \%$

Tabel 3. Rata-Rata Jumlah Daun pada Perlakuan Media Tanam

\begin{tabular}{ccccc}
\hline \multirow{2}{*}{ Media Tanam } & \multicolumn{4}{c}{ Jumlah Daun (helai) pada Umur Tanaman } \\
\cline { 2 - 5 } & 15 hst & 30 hst & 45 hst & 60 hst \\
\hline $\mathrm{m}_{1}$ & 2,46 & $4,32^{\mathrm{b}}$ & $5,01^{\mathrm{b}}$ & $6,82^{\mathrm{b}}$ \\
$\mathrm{m}_{2}$ & 2,21 & $3,44^{\mathrm{a}}$ & $4,11^{\mathrm{a}}$ & $5,58^{\mathrm{a}}$ \\
$\mathrm{m}_{3}$ & 2,17 & $3,43^{\mathrm{a}}$ & $4,99^{\mathrm{b}}$ & $6,79^{\mathrm{b}}$ \\
\hline
\end{tabular}

Keterangan : Angka-angka yang diikuti huruf yang sama menunjukkan tidak berbeda nyata berdasarkan uji BNT pada taraf $\alpha=5 \%$ 
Tabel 4. Rata-Rata Panjang Tangkai pada Perlakuan Media Tanam

\begin{tabular}{cc}
\hline Media Tanam & Panjang Tangkai $(\mathrm{cm})$ \\
\hline $\mathrm{m}_{1}$ & $54,04 \mathrm{~b}$ \\
$\mathrm{~m}_{2}$ & $45,59^{\mathrm{a}}$ \\
$\mathrm{m}_{3}$ & $53,07^{\mathrm{b}}$ \\
\hline Keterangan
\end{tabular}

Keterangan : Angka-angka yang diikuti huruf yang sama menunjukkan tidak berbeda nyata berdasarkan uji BNT pada taraf $\alpha=5 \%$

Tabel 5. Rata-Rata Jumlah Kuntum Bunga per Tangkai pada Perlakuan Media Tanam

\begin{tabular}{cc}
\hline Media Tanam & Jumlah Kuntum Bunga per Tangkai (kuntum) \\
\hline $\mathrm{m}_{1}$ & $13,06^{\mathrm{b}}$ \\
$\mathrm{m}_{2}$ & $11,08^{\mathrm{a}}$ \\
$\mathrm{m}_{3}$ & $11,63^{\mathrm{ab}}$ \\
\hline
\end{tabular}

Keterangan : Angka-angka yang diikuti huruf yang sama menunjukkan tidak berbeda nyata berdasarkan uji BNT pada taraf $\alpha=5 \%$

Hasil sidik ragam menunjukkan bahwa penggunaan media tanam memberikan pengaruh sangat nyata terhadap rata-rata saat muncul tunas, tinggi tunas umur 15, 30, 45 dan 60 hari setelah tanam, jumlah daun umur 30, 45 dan 60 hari setelah tanam, panjang tangkai bunga dan jumlah kuntum bunga per tanaman tetapi tidak berpengaruh nyata terhadap rata-rata jumlah daun umur 15 hari setelah tanam, umur berbunga dan umur tanaman saat panen. Hasil penelitian menunjukkan bahwa pengaruh penggunaan media tanam terhadap rata-rata saat muncul tunas berbeda sangat nyata. Perlakuan $\mathrm{m}_{1}$ (top soil) menghasilkan saat muncul tunas tercepat yaitu 7,39 hari, sedangkan perlakuan $\mathrm{m}_{2}$ (top soil + pupuk kandang + pasir) menghasilkan saat muncul tunas terlambat yaitu 8,80 hari. Hal ini disebabkan pada perlakuan $\mathrm{m}_{1}$ (top soil) merupakan media tanam yang baik untuk pertumbuhan tanaman serta mempunyai kandungan unsur hara yang lebih baik dibandingkan dengan jenis media yang lain. Menurut Hardjowigeno (1989), bahwa tanah lapisan atas/top soil umumnya merupakan tanah yang relatif subur jika dibandingkan dengan tanah lapisan bawah (sub soil), lapisan ini merupakan media utama bagi perkembangan akar tanaman dengan kandungan unsur hara yang tinggi serta kelembaban tanah menguntungkan bagi pertumbuhan dan perkembangan tanaman. Di tambahkan oleh Harjadi (2002), bahwa faktor yang paling utama dalam pertumbuhan tanaman adalah tanah yang memberikan unsur hara dan kelembaban tanah. Dengan adanya unsur hara yang cukup dan tersedia bagi tanaman akan dapat meningkatkan proses metabolisme di dalam tubuh tanaman sehingga dapat mempercepat proses pemunculan tunas. Sedangkan pada perlakuan $\mathrm{m}_{2}$ (top soil + pupuk kandang + pasir) mempunyai pori-pori lebih besar menyebabkan proses kehilangan air lebih cepat, sehingga proses metabolisme akan menjadi terhambat dan perkembangan vegetatif tanaman tidak dapat berlangsung secara maksimal. Sesuai dengan pendapat Harjadi (2002), bahwa kehilangan air dapat menghambat pertumbuhan tanaman dan defisiensi air yang terus-menerus akan menyebabkan perubahan-perubahan di dalam tubuh tanaman. Hasil penelitian menunjukkan bahwa pengaruh penggunaan media tanam terhadap rata-rata tinggi tunas umur 15, 30, 45 dan 60 hari setelah tanam berbeda sangat nyata. Perlakuan $\mathrm{m}_{1}$ (top soil) menghasilkan tinggi tanaman terbesar berturut-turut yaitu $12,29 \mathrm{~cm}$, $33,70 \mathrm{~cm}, 55,07 \mathrm{~cm}$ dan $64,59 \mathrm{~cm}$, sedangkan perlakuan $\mathrm{m}_{2}$ (top soil + pupuk kandang + pasir) menghasilkan tinggi tunas terkecil berturut-turut yaitu $9,78 \mathrm{~cm}, 27,18 \mathrm{~cm}, 49,45 \mathrm{~cm}$ dan $56,88 \mathrm{~cm}$. Hal ini diduga karena kandungan bahan organik pada perlakuan $\mathrm{m}_{1}$ (Top soil) lebih baik dibandingkan dengan media/perlakuan yang lain. Selain itu dengan kondisi struktur tanah yang baik maka penyerapan unsur hara oleh tanaman akan menjadi lebih baik pula. Dikatakan oleh sarief (1989), bahwa tanaman akan tumbuh dengan baik dan subur apabila unsur hara yang dibutuhkan tersedia dalam keadaan cukup dan seimbang. Sedangkan pada perlakuan $\mathrm{m}_{2}$ (top soil + pupuk kandang + pasir) mempunyai stuktur dan pori-pori yang besar/porous sehingga daya tahan terhadap air sangat kecil. Kemudian dengan kurangnya kandungan unsur hara pada media ini akan menyebabkan kurangnya makanan yang diperlukan oleh tanaman, sehingga proses metabolisme di dalam sel menjadi berkurang yang pada ahirnya menyebabkan pertumbuhan tanaman menjadi terhambat. Hasil penelitian menunjukkan bahwa pengaruh penggunaan media tanam terhadap rata-rata jumlah daun umur 30,45 dan 60 hari setelah tanam berbeda sangat nyata. Perlakuan $\mathrm{m}_{1}$ (top soil) menghasilkan jumlah daun terbanyak berturut-turut yaitu 4,32 helai, 5,01 helai dan 6,82 helai, sedangkan perlakuan $\mathrm{m}_{2}$ (top soil + pupuk kandang + pasir) menghasilkan jumlah daun terkecil berturut-turut yaitu 3,43 helai, 4,11 helai dan 5,58 helai. Hal ini disebabkan penyerapan dan pemanfaatan unsur hara pada perlakuan $\mathrm{m}_{1}$ (top soil) lebih baik bila 
dibandingkan dengan perlakuan lainnya. Pada perlakuan $\mathrm{m}_{1}$ (top soil) merupakan media tumbuh yang sangat baik bagi pertumbuhan tanaman, dengan kandungan unsur hara dan struktur yang baik serta sesuai bagi pertumbuhan tanaman, sehingga jumlah daun akan meningkat. Selain unsur hara yang diserap, faktor lingkungan seperti suhu memegang peranan penting dalam pembentukan daun, suhu dan ketersediaan air yang cukup mampu menggiatkan proses metabolisme di dalam pembentukan pucuk-pucuk daun (Saleh, 1986). Sedangkan pada perlakuan $\mathrm{m}_{2}$ (top soil + pupuk kandang + pasir) yang mempunyai pori-pori lebih besar menyebabkan proses kehilangan air lebih cepat, sehingga proses metabolisme akan menjadi terhambat dan perkembangan vegetatif tanaman tidak dapat berlangsung secara maksimal. Sesuai dengan pendapat Harjadi (2002), bahwa kehilangan air dapat menghambat pertumbuhan tanaman dan defisiensi air yang terus-menerus akan menyebabkan perubahan-perubahan di dalam tubuh tanaman. Hasil penelitian menunjukkan bahwa pengaruh penggunaan media tanam terhadap rata-rata jumlah daun umur 15 hari setelah tanam tidak berbeda nyata. Perlakuan $\mathrm{m}_{1}$ (top soil) menghasilkan jumlah daun terbanyak yaitu 2,46 helai, sedangkan perlakuan $m_{3}$ (top soil + pupuk kandang + sekam) menghasilkan jumlah daun terkecil yaitu 2,17 helai. Hal ini diduga karena bahan organik yang ada pada media tumbuh belum sepenuhnya dapat berfungsi dengan baik dan dimanfaatkan oleh tanaman. Menurut Hakim, dkk (1986), bahwa peranan bahan organik di dalam tanah ada yang bersifat langsung dan tidak langsung, tetapi sebagian besar mempengaruhi tanaman melalui sifat dan ciri tanah. Terhadap sifat fisik tanah, bahan organik sangat memberikan pengaruh terhadap kemampuan menahan air tanah serta merangsang granulasi agregat dan memanfaatkannya. Sedangkan untuk sifat kimia tanah, bahan organik meningkatkan daya serap dan kapasitas tukar kation. Pada sifat biologi tanah, bahan organik dapat memperbaiki jumlah dan aktifitas metabolik organisme tanah. Hasil penelitian menunjukkan bahwa pengaruh penggunaan media tanam terhadap rata-rata panjang tangkai bunga dan jumlah kuntum bunga per tanaman berbeda sangat nyata. Perlakuan $\mathrm{m}_{1}$ (top soil) menghasilkan panjang tangkai bunga dan jumlah kuntum bunga per tanaman terbesar yaitu $54,04 \mathrm{~cm}$ dan 13,06 helai, sedangkan perlakuan $\mathrm{m}_{2}$ (top soil + pupuk kandang + pasir) menghasilkan panjang tangkai bunga dan jumlah kuntum bunga per tanaman terkecil yaitu 45,59 $\mathrm{cm}$ dan 11,08 helai. Hal ini diduga karena kandungan bahan organik pada perlakuan $\mathrm{m}_{1}$ (top soil) lebih baik dibandingkan dengan media/perlakuan yang lain. Selain unsur hara yang diserap, faktor lingkungan seperti suhu memegang peranan penting dalam perkembangan vegetatif serta generatif tanaman. Sesuai pendapat Emi Malaysia (1989), bahwa selain dipengaruhi oleh kondisi lingkungan seperti media tanam, faktor iklim seperti suhu, kelembaban, dan cahaya merupakan faktor utama bagi pertumbuhan tanaman. Hasil penelitian menunjukkan bahwa pengaruh penggunaan media tanam terhadap rata-rata umur berbunga dan umur tanaman saat panen tidak berbeda nyata. Perlakuan $\mathrm{m}_{1}$ (top soil) menghasilkan umur berbunga dan umur tanaman saat panen terbesar yaitu 71,97 hari dan 71,24 hari, sedangkan perlakuan $\mathrm{m}_{3}$ (top soil + pupuk kandang + sekam) menghasilkan umur berbunga dan umur tanaman saat panen terlama yaitu 76,55 hari dan 75,25 hari. Hal ini diduga pertumbuhan generatif tanaman lebih dominan dipengaruhi oleh faktor dalam tanaman itu sendiri. Menurut Gardner (1991), bahwa pertumbuhan tanaman dipengaruhi oleh lingkungan (faktor eksternal) maupun faktor genetik (faktor internal). Ditambahkan oleh Darjanto dan Satifah (1990), bahwa peralihan dari masa vegetatif ke masa generatif selain dipengaruhi oleh faktor lingkungan juga ditentukan oleh oleh faktor dalam, yaitu sifat tanaman.

Tabel 6. Rata-Rata Tinggi Tanaman pada Perlakuan Pupuk Saputra Nutrien

\begin{tabular}{ccccc}
\hline Pupuk Saputra & \multicolumn{4}{c}{ Tinggi Tanaman $(\mathrm{cm})$ pada Umur Tanaman } \\
\cline { 2 - 5 } Nutrien & $15 \mathrm{hst}$ & $30 \mathrm{hst}$ & $45 \mathrm{hst}$ & $60 \mathrm{hst}$ \\
\hline $\mathrm{p}_{0}$ & $8,08^{\mathrm{a}}$ & 27,69 & $49,51^{\mathrm{a}}$ & $56,86^{\mathrm{a}}$ \\
$\mathrm{p}_{1}$ & $9,82^{\mathrm{ab}}$ & 29,91 & $50,51^{\mathrm{a}}$ & $59,02^{\mathrm{a}}$ \\
$\mathrm{p}_{2}$ & $11,11^{\mathrm{b}}$ & 30,33 & $50,96^{\mathrm{a}}$ & $61,91^{\mathrm{ab}}$ \\
$\mathrm{p}_{3}$ & $13,89^{\mathrm{c}}$ & 32,63 & $57,20^{\mathrm{b}}$ & $66,25^{\mathrm{b}}$ \\
\hline
\end{tabular}

Keterangan : Angka-angka yang diikuti huruf yang sama menunjukkan tidak berbeda nyata berdasarkan uji BNT pada taraf $\alpha=5 \%$ 
Tabel 7. Rata-Rata Umur Berbunga pada Perlakuan Pupuk Saputra Nutrien

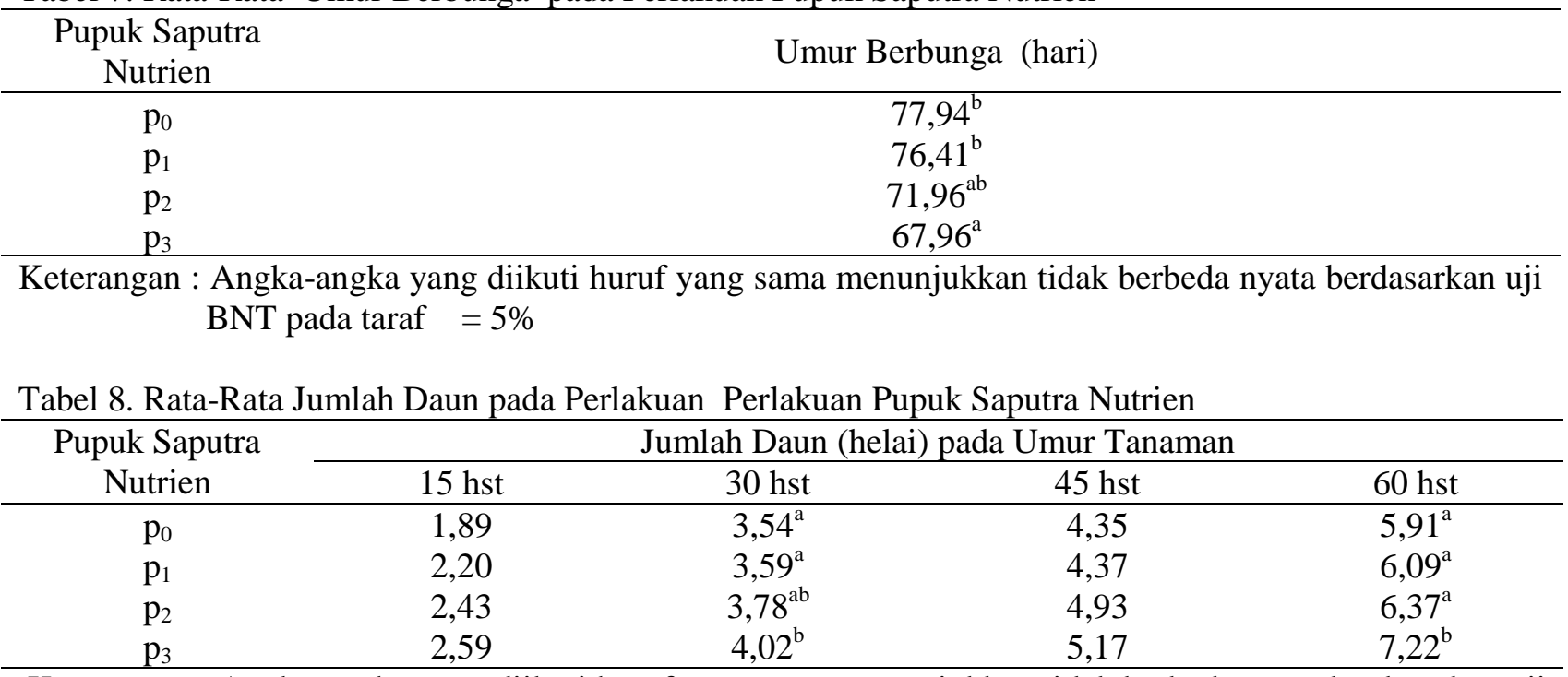

Keterangan : Angka-angka yang diikuti huruf yang sama menunjukkan tidak berbeda nyata berdasarkan uji BNT pada taraf $\alpha=5 \%$

Tabel 9. Rata-Rata Panjang Tangkai pada Perlakuan Pupuk Saputra Nutrien

\begin{tabular}{cc}
\hline $\begin{array}{c}\text { Pupuk Saputra } \\
\text { Nutrien }\end{array}$ & Panjang Tangkai $(\mathrm{cm})$ \\
\hline $\mathrm{p}_{0}$ & $47,34^{\mathrm{a}}$ \\
$\mathrm{p}_{1}$ & $49,02^{\mathrm{a}}$ \\
$\mathrm{p}_{2}$ & $50,71^{\mathrm{ab}}$ \\
$\mathrm{p}_{3}$ & $56,53^{\mathrm{b}}$ \\
\hline
\end{tabular}

Keterangan : Angka-angka yang diikuti huruf yang sama menunjukkan tidak berbeda nyata berdasarkan uji BNT pada taraf $\alpha=5 \%$

Tabel 10. Rata-Rata Jumlah Kuntum Bunga per Tangkai pada Perlakuan Pupuk Saputra Nutrien

Pupuk Saputra Nutrien

\begin{tabular}{cc}
\hline $\mathrm{p}_{0}$ & $10,22^{\mathrm{a}}$ \\
$\mathrm{p}_{1}$ & $11,28^{\mathrm{ab}}$ \\
$\mathrm{p}_{2}$ & $12,19^{\mathrm{b}}$ \\
$\mathrm{p}_{3}$ & $14,00^{\mathrm{c}}$ \\
\hline
\end{tabular}

Keterangan : Angka-angka yang diikuti huruf yang sama menunjukkan tidak berbeda nyata berdasarkan uji BNT pada taraf $\alpha=5 \%$

Hasil sidik ragam menunjukkan bahwa pupuk Saputra Nutrien memberikan pengaruh sangat nyata terhadap rata-rata saat muncul tunas, tinggi tanaman umur 15, 45 dan 60 hari setelah tanam, jumlah daun umur 30, 45 dan 60 hari setelah tanam, umur berbunga, panjang tangkai bunga dan jumlah kuntum bunga per tanaman, tetapi tidak berpengaruh nyata terhadap rata-rata saat muncul tunas, tinggi tanaman umur 30 hari setelah tanam, jumlah daun umur 15 hari setelah tanam dan umur tanaman saat panen.

Hasil penelitian menunjukkan bahwa pengaruh penggunaan pupuk Saputra Nutrien rata-rata saat muncul tunas tidak berbeda sangat nyata. Perlakuan $\mathrm{p}_{2}(1$ sendok makan powder $(3,5 \mathrm{~g})+3$ sendok liquid $(12 \mathrm{ml})+5,0$ liter air) menghasilkan saat muncul tunas tercepat yaitu 7,37 hari, sedangkan perlakuan $\mathrm{p}_{0}$ (tanpa pupuk) menghasilkan saat muncul tunas terlambat yaitu
8,48 hari. Hal ini diduga tanaman belum dapat menyerap unsur hara yang diberikan secara maksimal karena akar yang terbentuk belum dapat berfungsi sebagaimana mestinya. Disamping itu pengaruh pemberian pupuk Saputra Nutrien belum tampak optimal, sehingga ketersediaan unsur hara relatif lebih sedikit untuk mendukung pertumbuhan tanaman. Fungsi $\mathrm{N}$ menurut Jumin (1994), adalah untuk merangsang pertumbuhan vegetatif tanaman terutama daun, pertunasan, menambah tinggi tanaman, mempertinggi kemampuan tanaman untuk menyerap unsur hara lainnya seperti $\mathrm{P}$ dan $\mathrm{K}$.

Hasil penelitian menunjukkan bahwa pengaruh penggunaan pupuk Saputra Nutrien terhadap ratarata tinggi tunas umur 15, 45 dan 60 hari setelah tanam berbeda sangat nyata. Perlakuan $\mathrm{p}_{3}(1$ sendok makan powder $(3,5 \mathrm{~g})+3$ sendok liquid $(12 \mathrm{ml})+2,5$ liter air) menghasilkan tinggi 
tanaman terbesar berturut-turut yaitu $13,89 \mathrm{~cm}$, $57,20 \mathrm{~cm}$ dan $66,25 \mathrm{~cm}$, sedangkan perlakuan $\mathrm{P}_{0}$ (tanpa pupuk) menghasilkan tinggi tunas terkecil berturut-turut yaitu $8,08 \mathrm{~cm}, 49,51 \mathrm{~cm}$ dan 56,86 $\mathrm{cm}$. Hal ini diduga dengan pemberian pupuk Saputra Nutrien kedalam tanah memberikan hara yang diperlukan untuk pertumbuhan dan pupuk Saputra Nutrien mempunyai kandungan unsur hara makro dan mikro yang dibutuhkan untuk pertumbuhan tanaman. Sesuai dengan pendapat serief (1989), bahwa unsur hara yang diberikan pada tanaman sangat berguna untuk merangsang pertumbuhan akar, mambantu asimilasi dan pernapasan sekaligus meningkatkan jaringan tanaman yang membentuk titik tumbuh tanaman. Ditambah pula oleh Harjadi (2002), bahwa unsur nitrogen merupakan salah satu dasar pembentuk klorofil tanaman, dengan pupuk Saputra Nutrien yang diberikan pada tanah berarti semakin banyak klorofil yang dibentuk. Telah diketahui bahwa dengan banyaknya klorofil yang terbentuk maka proses fotosintesis akan berlangsung lebih baik sehingga mempengaruhi pertumbuhan tanaman termasuk tinggi tanaman.

Hasil penelitian menunjukkan bahwa pengaruh penggunaan pupuk Saputra Nutrien terhadap ratarata tinggi tunas umur 30 hari setelah tanam berbeda sangat nyata. Perlakuan $\mathrm{p}_{3}$ (1 sendok makan powder $(3,5 \mathrm{~g})+3$ sendok liquid $(12 \mathrm{ml})+$ 5,0 liter air) menghasilkan tinggi tanaman terbesar yaitu $32,63 \mathrm{~cm}$, sedangkan perlakuan $\mathrm{p}_{0}$ (tanpa pupuk) menghasilkan tinggi tunas terkecil berturut-turut yaitu $27,69 \mathrm{~cm}$. Hal ini disebabkan karena pada saat tanaman berumur 30 hari setelah tanam curah hujan yang terjadi cukup tinggi, sehingga bahan organik yang terkandung di dalam pupuk Saputra Nutrien tidak dapat tersedia dalam bentuk yang mudah diserap oleh tanaman. Menurut Buckman dan Brady (1982), proses perubahan nitrogen menjadi bentuk yang mudah diserap akan terhambat, apabila tanah dingin dan terendam air karena bakteri nitrifikasi sangat peka terhadap keadaan semacam ini.

Hasil penelitian menunjukkan bahwa pengaruh penggunaan pupuk Saputra Nutrien terhadap ratarata jumlah daun umur 30, 45 dan 60 hari setelah tanam berbeda sangat nyata. Perlakuan $p_{3}(1$ sendok makan powder $(3,5 \mathrm{~g})+3$ sendok liquid $(12 \mathrm{ml})+2,5$ liter air) menghasilkan jumlah daun terbanyak berturut-turut yaitu 4,02 helai, 5,17 helai dan 7,22 helai, sedangkan perlakuan $\mathrm{p}_{0}$ (tanpa pupuk) menghasilkan jumlah daun terkecil berturut-turut yaitu 3,54 helai, 4,35 helai dan 5,91 helai. Hal ini diduga karena tanaman tumbuh semakin besar maka jumlah daun semakin banyak, tergantung dari unsur hara yang diserapnya. Sesuai pendapat Dwidjoseputro (1996), bahwa dengan tersedianya unsur hara yang cukup maka proses fotosintesis tanaman akan semakin mneningkat, sehingga cadangan makanan yang banyak akan menstimulir pertumbuhan vegetatif tanaman terutama jumlah daun. Selain itu diduga bahwa dengan adanya kandungan unsur $\mathrm{Mg}$ yang terdapat pada pupuk Saputra Nutrien akan meningkatkan proses fotosintesis. Sesuai pendapat Sutejo (1995), bahwa Mg sangat berperan penting dalam pembentukan klorofil yang dibutuhkan dalam proses fotosintesis untuk menghasilkan karbohidrat. Dengan tersedianya karbohidrat yang merupakan bahan utama penyusun jaringan tanaman maka pertumbuhan tanaman akan berlangsung dengan baik sehingga jumlah daun akan meningkat. Menurut Harjadi (2002), bahwa laju pembelahan sel dalam penyusunan jaringan tanaman tergantung dari persediaan karbohidrat yang cukup.

Hasil penelitian menunjukkan bahwa pengaruh penggunaan pupuk Saputra Nutrien terhadap ratarata jumlah daun umur 15 hari setelah tanam tidak berbeda nyata. Perlakuan $\mathrm{p}_{3}$ (1 sendok makan powder $(3,5 \mathrm{~g})+3$ sendok liquid $(12 \mathrm{ml})+2,5$ liter air) menghasilkan jumlah daun terbanyak yaitu 2,59 helai, sedangkan perlakuan $\mathrm{p}_{0}$ (tanpa pupuk) menghasilkan jumlah daun terkecil yaitu 1,89 helai. Hal ini disebabkan karena sifat genetis dari bunga gladiol itu sendiri, yang menurut Herlina (1991), bahwa tanaman gladiol hanya membentuk daun yang berjumlah tujuh sampai delapan helai daun per tanaman hingga akhir siklus hidupnya, dan daun ini akan terbentuk lengkap pada saat tanaman sudah menampakkan bunganya. Selain itu kondisi perakaran yang belum terbentuk sempurna mengakibatkan tanaman belum dapat menyerap unsur hara yang diberikan secara maksimal, sehingga proses metabolisme pun akan menjadi terhambat seperti pembentukan pucuk-pucuk daun.

Hasil penelitian menunjukkan bahwa pengaruh penggunaan pupuk Saputra Nutrien terhadap ratarata umur berbunga, panjang tangkai bunga dan jumlah kuntum bunga per tanaman berbeda sangat nyata. Perlakuan $\mathrm{p}_{3}(1$ sendok makan powder $(3,5$ g) +3 sendok liquid $(12 \mathrm{ml})+5,0$ liter air) menghasilkan umur berbunga, panjang tangkai bunga dan jumlah kuntum bunga per tanaman terbesar yaitu 67,96 hari, $56,53 \mathrm{~cm}$ dan 14,00 kuntum, sedangkan perlakuan $\mathrm{p}_{0}$ (tanpa pupuk) menghasilkan umur berbunga, panjang tangkai bunga dan jumlah kuntum bunga per tanaman terkecil yaitu 77,94 hari, $47,34 \mathrm{~cm}$ dan 10,22 kuntum. Hal ini diduga dengan pemberian pupuk Saputra Nutrien dapat mmpercepat proses pembentukan bunga, dikarenakan pupuk Saputra Nutrien memiliki kandungan unsur hara yang lengkap, sehingga suplai unsur hara dalam tanaman terpenuhi dan dapat mempercepat proses pembetukan bunga, meningkatkan kualitas dan kuantitas bungan. Sesuai dengan pendapat Saputra (2007), bahwa Saputra Nutrien merupakan sumber nutrisi esensial yang terlarut dan berbentuk cair sehingga dapat dimanfaatkan langsung oleh 
tanaman dan seluruh organisme dalam tanah. Dengan tersedianya unsur hara yang dapat diserap langsung oleh tanaman, maka dapat meningkatkan pertumbuhan vegetatif yang pada akhinya akan mempercepat pertumbuhan generatif tanaman dalam hal ini adalah pembentukan bunga.

Hasil penelitian menunjukkan bahwa pengaruh penggunaan pupuk Saputra Nutrien terhadap ratarata umur tanaman panen tidak berbeda nyata. Perlakuan $\mathrm{p}_{3}(1$ sendok makan powder $(3,5 \mathrm{~g})+3$ sendok liquid $(12 \mathrm{ml})+5,0$ liter air) menghasilkan umur tanaman panen tercepat yaitu 71,41 hari, sedangkan perlakuan $\mathrm{p}_{0}$ (tanpa pupuk) menghasilkan umur tanaman panen terlama yaitu 74,83 hari. Hal ini disebabkan karena pada saat tanaman berumur 60 hari setelah tanam atau pada saat panen sudah memiliki sistem perakaran yang telah terbentuk sempurna, sehingga proses penyerapan unsur hara dari masing-masing tanaman relatif seimbang yang pada akhirnya tidak akan berpengaruh terhadap umur tanaman saat panen. Hal ini sesuai pendapat Foth (1991), bahwa semakin besar sistem perakaran dan

\section{KESIMPULAN}

1. Penggunaan media tanam berpengaruh nyata terhadap semua parameter penelitian, kecuali rata-rata jumlah daun umur 15 hari setelah tanam, umur berbunga dan umur tanaman saat panen $\mathrm{m}_{1}$ (top soil) menunjukkan jumlah kuntum bunga per tanaman terbesar yaitu 13,06 kuntum.

2. Penggunaan pupuk Saputra Nutrien berpengaruh nyata terhadap semua parameter

\section{DAFTAR PUSTAKA}

Asgar, A. Debora dan Toto Sutaler, 1995. Penggunaan Bahan Kimia Untuk Memacu Pertunasan Subang Gladiol (Kultivar Dt. Mansoer). Jurnal Hortikultura.

Ashari, S. 1995. Hortikultura. Aspek Budidaya. Universitas Indonesia, Jakarta.

Brady N. C. and Buckman, H. O. 1982. The Natureand Properties Of soil. Terjemahan Soegiman. Ilmu Tanah. Bharata Karya Aksara, Jakarta.

Dwijosepoetra, D. 1996. Pengantar Fisiologi Tumbuhan. Gramedia, Jakarta.

Foth, H.D. 1991. Fundamentals of Soil Science. Terjemahan E.D. Purbayanti, D.R. Lukawati, R. Timulasih. Dasar-dasar Ilmu Tanah. Univ. Gadjah Mada Press, Yogyakarta. percabangan akar, maka kemampuan tanaman untuk menyerap unsur hara dari dalam tanah akan meningkat juga. Dari hasil analisis ragam dapat diketahui bahwa interaksi antara penggunaan media tanam dan pupuk Saputra Nutrien tidak berpengaruh nyata terhadap semua parameter penelitian. Tidak adanya pengaruh nyata dikarenakan masing-masing faktor memberikan faktor terpisah terhadap pertumbuhan tanaman sehingga apabila dikombinasikan tidak akan saling mempengaruhi. Sesuai pendapat Steel dan Torrie (1993), bahwa apabila antara dua faktor tidak berpengaruh nyata maka dapat disimpulkan bahwa faktor-faktor tersebut bertindak bebas satu dengan lainnya. Meskipun berpengaruh tidak nyata kombinasi antara penggunaan media tanam $\mathrm{m}_{1}$ (top soil) dan konsentrasi pupuk Saputra Nutrien $\mathrm{P}_{3}(1$ sendok makan powder $(3,5 \mathrm{~g})+3$ sendok liquid $(12 \mathrm{ml})+2,5$ liter air) cenderung memperlihatkan hasil yang terbaik terhadap semua parameter yang diamati dibandingkan perlakuan lainnya.

penelitian, kecuali saat muncul tunas, tinggi tanaman umur 30 hari setelah tanam, jumlah daun umur 15 hari setelah tanam dan umur tanaman saat panen. Perlakuan $\mathrm{p}_{2}(1$ sendok makan powder +3 sendok makan liquid $+5,0$ $\mathrm{L}^{-1}$ ) menunjukkan jumlah kuntum bunga per tanaman terbesar yaitu 14,00 kuntum.

3. Interaksi penggunaan media tanam dan pupuk Saputra nutrien memberikan pengaruh tidak nyata terhadap semua parameter penelitian.

Gardner, F.P, R.B. Pearce and R. L. Mitchell. 1991. Physiology of Corp Plant. Terjemahan Herawati Susilo. Fisiologi Tanaman Budidaya. UI Press, Jakarta.

Hakim, N., M. Y. Nyakpa, A. M. Lubis, S. G. Nugroho, M. R.Saul, M. N. Diha, G. B. Hong, H. H. Bailey. 1986. Dasar-Dasar Ilmu Tanah. Unila, Lampung.

Hardjowigeno,S. 1989. Ilmu Tanah. Medyatama Sarana Swadaya, Jakarta.

Harjadi, S. S. 2002. Pengantar Agronomi. Gramedia, Jakarta.

Herlina, D. 1991. Gladiol. Penebar Swadaya, Jakarta.

Jumin, H. B. 1994. Dasar-Dasar Agronomi. Rajawali, Jakarta. 
Olieve Wisje, 1994. Pengaruh Ukuran Subang dan Kedalaman Tanam Terhadap Pertumbuhan dan Produksi Gladiol (Gladiolus hibridus). Skripsi Faferta UNMUL. Samarinda (Tidak Dipublikasikan)

Riyanto dan Soehartini Riyanto, 1981. Agroferestri dan Profeknya di KALTIM. Balitan Hutan Direktorat Reboisasi Rehabilitasi, Jakarta.

Rukmana. R. 2000. Gladiol Prospek Agribisnis dan Teknik Budidaya. Kanisius, Yogyakarta.

Saleh. 1986. Pupuk dan Cara Pemupukan. Terjemahan Risema, Bharata Karya Aksara, Jakarta.

Saputra N. 2007. Saputra Nutrient. Bogor.

Sarief, S.E. 1989. Kesuburan dan Pemupukuan Tanah Pertanian. Pustaka Buana, Bandung.

Satifah dan Darjanto. 1990. Pengetahuan Dasar Biologi Bunga dan Tehnik Penyerbukan Silang Buatan. Gramedia, Jakarta.

Steel R.G.D., and J.H. Torrie, 1991. Prinsiples and Procedure Of Statistik. Terjemahan B. Sumantri. Prinsip dan Prosedur Statistik. Gramedia, Jakarta.

Sutejo, M. M. 1994. Pupuk dan Cara Pemupukan. Rineka cipta, Jakarta.

Winata, I. K. 1985. Tanaman Hias Ruang. Kanisius, Yogyakarta. 